\title{
Lead speciation in ambient urban air
}

\author{
E. TEPER ${ }^{1 *}$, M. JABŁOŃSKA ${ }^{2}$, J. JANECZEK $^{3}$, \\ M. RACHWAŁ ${ }^{4}$, W. ROGULA-KOZLOWSKA ${ }^{5}$
}

${ }^{1,2,3}$ Institute of Earth Sciences, Uniwersity of Silesia, Będzińska 60, 41-200 Sosnowiec, Poland,

(*correspondence: ewa.teper@us.edu.pl;

${ }^{2}$ (mariola.jablonska@us.edu.pl)

3(janusz.janeczek@us.edu.pl)

${ }^{4,5}$ Institute of Environmental Engineering, Polish Academy of Sciences in Zabrze, Poland

${ }^{4}$ (marzena.rachwal@ipis.zabrze.pl)

5(wioletta.rogula-kozlowska@ipis.zabrze.pl)

Despite leaded-fuel bans for road vehicles in many countries, lead in the air is still a problem because there are numerous other emission sources of this potentially toxic metal. The role of lead speciation is important for evaluating its mobility and bioavailability.

Total suspended particulates (TSP) and fine particles (PM1) were collected from October 2018 to March 2019 in the city of Zabrze with the aim of determining lead species in the ambient air. Zabrze is located within the Upper Silesian conurbation - one of the most urbanized and industrialized regions of Europe, notorious for poor air quality in winter.

The lead contents in TSP was determined by ICP-OS and ranged from 6 to $110 \mathrm{ppm} / \mathrm{m}^{3}$ (median $28 \mathrm{ppm} / \mathrm{m}^{3}$ ). The analytical Quanta 250 scanning electron microscope was used for lead-bearing single-particle characterization. The following lead species were observed in TSP and PM1 (listed in decreasing abundance): chloride, sulfate, carbonate, oxide, and arsenate. Most of the lead-bearing particles were submicron in size, though some of lead carbonate particles observed in TSP exceeded $10 \mu \mathrm{m}$ in diameter. Lead-bearing particles were associated with calcium carbonates, calcium and magnesium carbonates, calcium sulfates, and with mixed $\mathrm{Na}-, \mathrm{K}-$, and Mg-sulfates.

Lead chloride, oxide, and sulfate most probably are related to coal combustion. The occurrence of euhedral lead arsenate particles is more problematic. The arsenic contents in TSP ranged from $1 \mathrm{ppm} / \mathrm{m}^{3}$ to $5 \mathrm{ppm} / \mathrm{m}^{3}$ (median $2.5 \mathrm{ppm}$ $/ \mathrm{m}^{3}$ ). The association of lead arsenate with lead carbonate particles suggests lead ores processing as their emission source. The use of waste rock from the past lead and zinc mining as aggregate in construction applications is a common practise in the region, including the city of Zabrze.

This study was financially supported by the National Science Centre grant UMO-2016/23/B/ST10/02789 